\title{
THE EFFECT OF PLANTATION SILVICULTURE ON SOIL ORGANIC MATTER AND PARTICLE-SIZE FRACTIONS IN AMAZONIA ${ }^{(1)}$
}

\author{
Troy Patrick Beldini ${ }^{(2)}$, Kenneth L. McNabb ${ }^{(3)}$, B. Graeme \\ Lockaby $^{(3)}$, Felipe G. Sanchez ${ }^{(4)}$, Osvaldo Navegantes-Câncio ${ }^{(5)} \&$ \\ Raimundo Cosme de Oliveira ${ }^{(6)}$
}

\begin{abstract}
SUMMARY
Eucalyptus grandis and other clonal plantations cover about 3.5 million ha in Brazil. The impacts of intensively-managed short-rotation forestry on soil aggregate structure and Carbon (C) dynamics are largely undocumented in tropical ecosystems. Long-term sustainability of these systems is probably in part linked to maintenance of soil organic matter and good soil structure and aggregation, especially in areas with low-fertility soils. This study investigated soil aggregate dynamics on a clay soil and a sandy soil, each with a Eucalyptus plantation and an adjacent primary forest. Silvicultural management did not reduce total C stocks, and did not change soil bulk density. Aggregates of the managed soils did not decrease in mass as hypothesized, which indicates that soil cultivation in 6 year cycles did not cause large decreases in soil aggregation in either soil texture. Silt, clay, and $\mathrm{C}$ of the sandy plantation soil shifted to greater aggregate protection, which may represent a decrease in $\mathrm{C}$ availability. The organic matter in the clay plantation soil increased in the fractions considered less protected while this shift from $\mathrm{C}$ to structural forms considered more protected was not observed.
\end{abstract}

Index terms: Jari, soil structure, subsoiling, sustainability.

\footnotetext{
(1) Este trabalho foi realizado como parte da tese de doutorado feito com o apoio do grupo ND-08 do Projeto LBA. Pesquisador do Programa DCR, CNPq/FAPESPA. Recebido para publicação em fevereiro de 2009 e aprovado em julho de 2009.

(2) Pesquisador, Large-scale Biosphere Atmosphere Experiment. Legião Brasileira de Assistência - LBA. Rua 24 de outubro 3707, CEP 68040-010 Santarém (PA). E-mail: tpbeldini@yahoo.com

(3) Professor, Auburn University School of Forestry and Wildlife Sciences, Auburn AL, USA 36849. Emails: mcnabkl@auburn.edu; lockabg@auburn.edu

(4) Pesquisador, USDA Forest Service, Southern Research Station, 3041 Cornwallis Road, P.O. Box 12254, Research Triangle Park, NC, USA. E-mail: fsanchez@fs.fed.us

(5) Pesquisador, Projeto Florestal da Vale. CEP 68633-000 Dom Eliseu (PA). E-mail: ocancio@yahoo.com.br

(6) Pesquisador, Embrapa Amazônia Oriental. CEP 68040-010 Santarém (PA). E-mail: cosme@lbasantarem.com.br
} 


\title{
RESUMO: O EFEITODE MANEJO SILVICULTURAL DE EUCALIPTO SOBRE MATÉRIA ORGÂNICA E FRAÇÕES DE SOLO NA AMAZÔNIA
}

\begin{abstract}
Este trabalho teve como objetivo investigar a dinâmica dos agregados do solo e das suas frações derivadas dos mesmos em duas texturas de solo, cada uma com uma plantação de Eucalipto e uma floresta primaria imediatamente adjacente. Eucalyptus grandis e outros clones cultivados em plantações cobrem aproximadamente 3,5 milhões de hectares no Brasil. Os impactos de manejo intensivo de plantações de rotação curta sobre a estrutura de solo e a dinâmica de carbono $(C)$ são em grande parte desconhecidos em ecossistemas tropicais. No longo prazo, a sustentabilidade desses sistemas é provavelmente ligada à manutenção da matéria orgânica e à estrutura de agregação do solo, principalmente em áreas de solos de baixa fertilidade. Manejo silvicultural não diminuiu os estoques de C total, e não mudou a densidade do solo. Agregados dos solos manejados não diminuíram em massa, o que indica que a subsolagem e o manejo em ciclos de 6 anos não causaram um efeito negativo na agregação do solo em ambas as texturas. Os agregados do solo arenoso sob plantio aumentaram seus conteúdos de silte, argila e $C$, indicando que, na estrutura de agregação do solo, Cestá mudando para um ambiente de maior proteção contra decomposição. O solo argiloso sob plantio teve um aumento de matéria orgânica contida nas frações consideradas menos protegidas, e não demonstrou essas mudanças de $C$ para formas estruturais consideradas mais protegidas.
\end{abstract}

Termos de indexação: Jari, estrutura do solo, subsolagem, sustentabilidade.

\section{INTRODUCTION}

Soil organic matter (SOM) is important for the maintenance of soil structure and fertility (Shang \& Tiessen, 1998; Fisher \& Binkley, 2000). The soil structure has been represented in a model proposed by Tisdall \& Oades (1982) based on macro- and microaggregates and free primary particles. Soil microaggregates are the basic structural soil units (Edwards \& Bremner, 1967; Gregorich et al., 1991; Hassink et al., 1997). These are $<0.250 \mathrm{~mm}$ diameter, claypolyvalent, metal-organic matter complexes (Edwards \& Bremner 1967; Tisdall \& Oades 1982). Soil organic matter is protected within soil aggregates in undisturbed soils; upon disturbance of aggregates by cultivation, the SOM may become vulnerable to accelerated decomposition or redistribution to less labile soil particle-size fractions (Tiessen \& Stewart, 1983; Cambardella \& Elliot, 1994; Hassink et al., 1997; Six et al., 2000). As soil aggregation is broken up, organic matter trapped within aggregates becomes available for oxidation or can be transferred to smaller aggregate- and particle-size classes where it becomes chemically bound and less effective for nutrient cycling and structural stability than the original organic matter in virgin soil (Tiessen \& Stewart, 1983; Sollins et al., 1996). The transformation endpoint of this organic matter transformation to smaller particle size fractions would most likely be chemical protection by bonding with mineral surfaces to form organomineral complexes and subsequent physical protection within micro-aggregates. The incorporation of SOM into a more protected micro-environment is characterized by a depletion of labile fractions and a shift towards fine silt, coarse clay, and microaggregate-associated materials with low nutrient availability (Tiessen \& Stewart, 1983; Sollins et al., 1996), possibly reducing the long-term sustainability of intensive soil management. Besides the greater degree of physical protection, SOM contained within micro-aggregates is generally considered to be more decomposed or more recalcitrant than SOM contained in larger aggregates (Lützow et al., 2007).

Studies analyzing SOM in the context of soil aggregates and particle size fractions of highlyweathered soils in tropical environments have shown mixed results. In an analysis of a Brazilian Oxisol after 6 years of shifting cultivation, Shang \& Tiessen (1997) showed that the soil lost $13 \%$ of the original SOM. Furthermore, they found that the soil sand fraction lost SOM while the clay fraction increased in SOM due to a shift of SOM from the sand- and siltsized particles. Zinn et al. (2005), comparing uncultivated and cultivated comparable sites in Brazil, reported no changes in SOM of Oxisols under various types of agricultural activities. In Brazil, an area of approximately 3.5 million ha was afforested with Eucalyptus species (SBS, 2005), and the productivity is increasing (Jari, 2008; Sinpapel, 2008; Aracruz, 2009). For example, Eucalyptus plantations of Jari Celulose in the State of Pará, in the Brazilian Amazon region, have increased in productivity from $14 \mathrm{~m}^{3} \mathrm{ha}^{-1}$ year-1 in 1990, to $30 \mathrm{~m}^{3} \mathrm{ha}^{-1}$ year-1 in 2008, and yields are projected to increase to $38 \mathrm{~m}^{3} \mathrm{ha}^{-1}$ year $^{-1}$ in the next few years. In the light of such production increases, the inevitable question of the impacts of afforestation and management on soil resources arises. The effects of afforestation with Eucalyptus species 
in Brazil have been shown to increase soil carbon stocks (Maquere et al., 2008), decrease soil carbon in the $0-5 \mathrm{~cm}$ layer (Zinn et al., 2002), or to have no effect on soil carbon (Zinn et al., 2005) or nitrogen stocks (Maquere et al., 2008). Lima et al. (2006), working in a short-rotation Eucalyptus plantation on degraded pasture on a clayey Typic Haplustox, in south-eastern Brazil, found SOM increases in all soil fractions analyzed, compared to adjacent pasture. SOM increases were also found for various soil fractions in a clayey Rhodic Ustox. Studies examining SOM dynamics in fractions of Eucalyptus plantation soils in the Brazilian Amazon, where the means of annual temperature and precipitation are higher, are scarce in the literature.

The objective of this research was to analyze changes in aggregate structure, carbon, and nitrogen storage in soil aggregates and particle size fractions and to assess the effects of soil disturbance on tropical tree plantations. Specifically, it was hypothesized that decades of soil disturbance by plantation silviculture at the Jari site resulted in: a decrease in total $\mathrm{C}$, increases in soil bulk density in the surface layers, a shift of soil C from labile to stabile forms, and a decrease in soil aggregation. Besides, particle-size fractionation would reveal a higher $\mathrm{C}$ percentage in silt- and clay particle size fractions in microaggregates in the plantation soils than in the primary forest soils.

\section{MATERIAL AND METHODS}

This research was conducted in an area of Jari Celulose S.A., Monte Dourado, State of Pará, Brazil. The company manages about 55,000 ha of Eucalyptus spp. (Bauch et al., 2005) harvested in 6-year rotations and produces bleached kraft pulp for the international and domestic market (McNabb \& Wadouski, 1999). Further details of the history of the Jari company were reported by Fearnside (1988), McNabb et al. (1994), and McNabb \& Wadauski (1999). The regional climate is classified as Amw - hot and humid in the Köppen system. Rainfall averages $2,115 \mathrm{~mm}$ annually, varying from $290 \mathrm{~mm}$ in May to $41 \mathrm{~mm}$ in
October, with a brief but distinct dry season from September to November. The average annual temperature is $26.4^{\circ} \mathrm{C}$, varying less than $2^{\circ}$ monthly. The natural vegetative cover can be classified as tropical ombrophilous lowland forest (UNESCO, 1973).

This study investigated the same parameters in a clayey Oxisol (Haplustox) and a sandy Ultisol (Hapludult) in Eucalyptus plantations and adjacent primary forest of each soil type. The soil texture data were provided by Jari Celulose and the soil profile descriptions were established by the pipette method (Table 1).

The clearing of areas of native forest for plantations began in 1968. Each site was converted from native forest (sandy site in 1971; clay site in 1988) by largescale slash-and-burn methods. The methods of site preparation varied throughout the history of rotations at each site, but included burning, root raking, soil ripping or sub-soiling to $\approx 50 \mathrm{~cm}$ (Table 2 ).

Planting beds were prepared and seedlings were hand-planted at a spacing of $3 \times 3 \mathrm{~m}$. The planting material came from clonally propagated stock matched to the specific conditions at each site.

At each site, a plantation ( $E$. grandis x $E$. urophylla) and an adjacent $(<5 \mathrm{~m})$ primary forest area were investigated. The study sites were selected according to the following criteria: (1) immediate proximity of native forest and actively-managed plantations; (2) status of undisturbed native forest, i.e., no history of wood harvesting; (3) availability of plantation history; (4) unhindered access to the sites; and (5) uniformity of soil of plantation and native forest. Extensive field surveys, soil maps and aerial photos were used to choose these sites. At each study site the relief, slope, soil parent material and texture were the same for both forest types.

Eight sample plots of $100 \mathrm{~m}^{2}(10 \times 10 \mathrm{~m})$ were established at each site, four in the plantation and four in the native forest. Soil samples were taken from four randomly selected locations in each plot during July 2001, by a bucket auger. The soil samples were collected from the layers $0-20 \mathrm{~cm}$ and $30-50 \mathrm{~cm}$ and bulked across the samples of each plot. A $2 \mathrm{~kg}$ composite sample was taken at each depth after

Table 1. Soil texture, clay and sandy soils in plantation and native forests, Jari

\begin{tabular}{|c|c|c|c|c|}
\hline \multirow{2}{*}{ Depth } & \multicolumn{2}{|c|}{ Clayey Haplustox } & \multicolumn{2}{|c|}{ Sandy Hapludult } \\
\hline & Native & Plantation & Native & Plantation \\
\hline $\mathrm{cm}$ & \multicolumn{4}{|c|}{ sand, silt, clay $\left(\mathrm{g} \mathrm{kg}^{-1}\right)$} \\
\hline$(0-25)$ & $30,90,880$ & $30,90,880$ & $910,20,70$ & $910,20,70$ \\
\hline$(25-60)$ & $20,100,880$ & $20,100,880$ & $820,30,150$ & $820,30,150$ \\
\hline$(60-100)$ & $20,130,850$ & $20,130,850$ & $790,40,170$ & $790,40,170$ \\
\hline
\end{tabular}


Table 2. Silvicultural treatment for current rotation

\begin{tabular}{|c|c|c|}
\hline Parameter & Clay soil & Sandy soil \\
\hline Tree species on site & E. grandis x E. urophylla & E. grandis x E. urophylla \\
\hline Soil preparation method & Mechanical ripping to $\approx 50 \mathrm{~cm}$ & Mechanical ripping to $\approx 50 \mathrm{~cm}$ \\
\hline Date planted & July 1995 & April 1994 \\
\hline Tree spacing (m) & $3,0 \times 3,0$ & $3.5 \times 2.6$ \\
\hline Trees planted per hectare & 1,111 & 1,099 \\
\hline $\begin{array}{l}\text { Fertilizing regime } 30 \text { days } \\
\text { before planting }\end{array}$ & $\begin{array}{l}\text { June } 1995 \text {. Broadcast application } \\
\text { of rock phosphate }\left(59 \mathrm{~kg} \mathrm{ha}^{-1}\right. \\
\text { elemental P) }\end{array}$ & $\begin{array}{l}\text { March } 1994 . \text { Broadcast application } \\
\text { of rock phosphate }\left(40 \mathrm{~kg} \mathrm{ha}^{-1}\right. \\
\text { elemental P) }\end{array}$ \\
\hline $\begin{array}{l}\text { Fertilizing regime at time of } \\
\text { planting (manually applied } \\
\text { to base of seedlings) }\end{array}$ & $\begin{array}{l}65 \mathrm{~kg} \mathrm{ha}-1 \text { elemental P } \\
\text { NPK }(15-15-15)=150 \mathrm{~g} / \text { plant }\end{array}$ & $\begin{array}{l}65 \mathrm{~kg} \mathrm{ha}-1 \text { elemental P } \\
\text { NPK }(15-15-15)=90 \mathrm{~g} / \text { plant }\end{array}$ \\
\hline $\begin{array}{l}\text { Fertilizing regime } 90 \text { to } \\
120 \text { days after planting }\end{array}$ & $\begin{array}{l}185 \mathrm{~kg} \mathrm{ha}^{-1} \mathrm{NPK}(15-10-20) \\
\text { elemental N/P/K: 28/8/31 }\end{array}$ & $\begin{array}{l}165 \mathrm{~kg} \mathrm{ha}{ }^{-1} \mathrm{NPK}(15-10-20) \\
\text { elemental N/P/K: } 25 / 7 / 27\end{array}$ \\
\hline $\begin{array}{l}\text { Fertilizing regime months } \\
\text { after planting }\end{array}$ & none & $\begin{array}{l}100 \mathrm{~kg} \mathrm{ha}{ }^{-1} \mathrm{NPK}(15-10-20) \\
\text { elemental N/P/K: 15/4.4/17 }\end{array}$ \\
\hline $\begin{array}{l}\text { Fertilizing regime } 24 \text { months } \\
\text { after planting }\end{array}$ & $\begin{array}{l}300 \mathrm{~kg} \mathrm{ha}{ }^{-1} \text { dolomite } 220 \mathrm{~kg} \mathrm{ha}^{-1} \\
\text { NPK } 15-10-20\end{array}$ & $\begin{array}{l}200 \mathrm{~kg} \mathrm{ha} \mathrm{ha}^{-1} \text { dolomite } 100 \mathrm{~kg} \mathrm{ha}^{-1} \\
\text { NPK } 15-10-20\end{array}$ \\
\hline \multirow[t]{3}{*}{ Weed control } & $\begin{array}{l}\text { Pre-plant herbicide on one meter } \\
\text { wide area of tree rows }\end{array}$ & $\begin{array}{l}\text { Pre-plant herbicide on one meter } \\
\text { wide area of tree rows }\end{array}$ \\
\hline & $\begin{array}{l}\text { Pre-plant emergent herbicide } \\
60 \text { days after planting }\end{array}$ & $\begin{array}{l}\text { Pre-plant emergent herbicide } \\
60 \text { days after planting }\end{array}$ \\
\hline & $\begin{array}{l}\text { Pre-plant emergent herbicide } \\
120 \text { days after planting }\end{array}$ & $\begin{array}{l}\text { Pre-plant emergent herbicide } \\
120 \text { days after planting }\end{array}$ \\
\hline Manual cleaning & $\begin{array}{l}\text { Every two months up to } 1.5 \text { years } \\
\text { of age, then once per year until } \\
\text { crown closure }\end{array}$ & $\begin{array}{l}\text { Every two months up to } 1.5 \text { years } \\
\text { of age, then once per year until } \\
\text { crown closure }\end{array}$ \\
\hline
\end{tabular}

thorough mixing in the field. Soil samples for the analyses of total carbon pool were taken in May 2002 and January 2003. A soil pit was dug (depth $1 \mathrm{~m}$ ) at a randomly chosen points of each plot for a total of 16 pits across the two study sites. Samples were collected from the layers $0-25,25-60$, and $60-100 \mathrm{~cm}$ by collecting soil from the entire depth interval, mixing thoroughly, and then taking a sub-sample. Samples for bulk density were also taken in these pits together with the samples taken for the analyses of total carbon pools. The clod method was used to determine bulk density (Blake \& Hartage, 1986). Three replicate soil clods were taken at the midpoint of each of the three sampling depths in each soil pit, and the mean of the three replications was considered the bulk density value for that depth. This sampling scheme resulted in 24 samples per forest $\mathrm{x}$ texture combination for the two sampling years.

After sampling, soil samples for all analyses were immediately transported to the laboratory, stored at field moisture in sealed plastic bags in a $4^{\circ} \mathrm{C}$ cooler, and analyzed within 2 weeks after field sampling. Sub- samples of all soils were dried at $105^{\circ} \mathrm{C}$ to determine moisture content. Carbon was determined on sieved $(2.8 \mathrm{~mm})$, air-dried and ground sub-samples through dry combustion analysis in a Perkin-Elmer 2400 series II CHNS/O analyzer (Perkin-Elmer Corp., Norwalk, CT). The values of the 2002 and 2003 samples were combined for statistical analysis because of the very low variation within a sampling site for each sampling year, and because this study did not test for seasonality differences. The total $\mathrm{C}$ of a given sampling depth was calculated based on the $\mathrm{C}$ concentrations using soil bulk density, mass, and volume at that depth. The total $\mathrm{C}$ in the one-meter soil profile was calculated as the sum of the three depths.

The procedure used for the isolation of aggregates and particle size fractions generally followed the protocol described by Cambardella \& Elliot (1994). The entire field-moist soil sample was passed through a $2.8 \mathrm{~mm}$ sieve and then a sub-sample was taken to determine the gravimetric moisture content. The soil moisture content of each soil sample used in the 
fractionation procedure was adjusted to a common level following the recommendations of Elliot \& Cambardella (1991). The initial $100 \mathrm{~g}$ oven-dried sample used in the wet-sieving procedure was capillary-wetted overnight at $4{ }^{\circ} \mathrm{C}$ while spread on presoaked Whatman filter paper to raise the sample moisture to field capacity. The field capacity of the soils had been determined by previous experimentation. The sample was then wet-sieved through a series of three nested sieves to obtain two aggregate fractions: 0.250 to $2 \mathrm{~mm}$ (small macroaggregates - SMAG), and 0.053 to $0.250 \mathrm{~mm}$ (microaggregates - MIAG).

The sieving apparatus was a RoTap model RX-29 (W.S Tyler, Salisbury, NC), used without the tapping action of the hammer arm. The sieving cycle lasted $2 \mathrm{~min}$, at a water flow rate of $1,750 \mathrm{~mL} / \mathrm{min}$. Each aggregate fraction was dried overnight at $50{ }^{\circ} \mathrm{C}$ and weighed, and the mass of the aggregate fraction was calculated as the \% of dry soil resulting from an ovendried amount equivalent to $100 \mathrm{~g}$ of field-moist soil. The SMAG and MIAG fractions were then sonicated to disrupt aggregation. SMAG were divided into $10 \mathrm{~g}$ sub-samples, placed in $55 \mathrm{~mL}$ water and stirred, then sonicated for $3 \mathrm{~min}$ at $15 \%$ of maximum power output (82.5 W, or 1,450 $\mathrm{J} \mathrm{g}^{-1}$ of soil) on a XL-2020 ultrasonic liquid processor, (Misonix Inc., Farmingdale, NY). The sonicated SMAG fraction was then sieved through sieve sizes $0.250-, 0.053-$, and $0.025 \mathrm{~mm}$ in the sieving machine, and the $<0.025 \mathrm{~mm}$ fraction was collected. The fractions remaining on the sieves (0.250-, 0.053-, and $0.025 \mathrm{~mm}$ ) were dried at $50{ }^{\circ} \mathrm{C}$ overnight, weighed the next day and stored. The $<0.025 \mathrm{~mm}$ fraction was centrifuged to isolate the medium/fine silt (0.002$0.025 \mathrm{~mm}$ ) and the coarse clay $(0.0002-0.002 \mathrm{~mm})$ fractions. The centrifuge regime used to isolate the medium/fine silt fraction was $3 \mathrm{~min}$ at $750 \mathrm{rpm}$, and that for the coarse clay fraction was $19 \mathrm{~min}$ at 4,000 rpm. These centrifuge regimes were determined through experimentation and based on the recommendations of Jackson (1956). The MIAG fraction derived from the initial sieving was sonicated in an identical protocol as used for SMAG.

Once the 9 fractions were derived for all 32 soil samples, the entire content of each fraction was weighed and ground. Sub-samples $(1.5 \mathrm{mg})$ were analyzed for total $\mathrm{C}$ by dry combustion. The mass of each particle size fraction was represented as \% of the original SMAG or MIAG aggregate fraction. $\mathrm{C}$ in the particle size fractions was calculated based on the oven-dry mass of that fraction and its carbon concentration. The $\mathrm{C}$ of each particle size fraction derived from SMAG or MIAG was then summed across the fractions to obtain the $\mathrm{C}$ contents in SMAG and MIAG. All results were reported on an oven-dry mass basis. Statistical analyses were performed using SAS version 8 (SAS, 2001). Residuals from all analyses were checked for normality and homogeneity of variances (Steel \& Torrie, 1980). Contrast tests were used to test for differences between forest types within a soil texture for clay native soil versus clay plantation soil, and sandy native soil versus sandy plantation soil within a depth. Contrasts were used to separate means because comparisons of plantation and native forests had been decided a priori. No comparisons were made between depths for any variable. A probability level of 0.05 was used for all significance tests.

\section{RESULTS}

Contrast tests for total $\mathrm{C}$ in each depth yielded $\mathrm{p}$ values of 0.92 for forests on the sandy soil, and 0.75 for forests on the clay soil indicating that each forest within a soil texture had an equal amount of $\mathrm{C}$, and that total soil $\mathrm{C}$ did not diminish under intensive plantation management (Table 3).

Comparing $\mathrm{C}$ stocks within each texture for each depth sampled, no differences were found between plantation and native forest (Table 3). The statistically equal distribution at each depth for the forest and texture combinations indicates that management has reduced neither the total amount of $\mathrm{C}$ nor its distribution in the profile of the managed soils.

\section{Aggregate mass and carbon dynamics}

The recovery of particle size fractions averaged $99.5 \%$ indicating negligible losses during the fractionation procedure. The analysis of mass and $\mathrm{C}$

Table 3. Total soil $\mathrm{C}\left(\mathrm{Mg} \mathrm{ha}^{-1}\right)$ and bulk density $\left(\mathrm{Mg} \mathrm{m}^{-3}\right)$ at two depths for forest $\mathrm{x}$ texture

\begin{tabular}{|c|c|c|c|c|}
\hline & Sandy Soil Plantation & Sandy Soil Native & Clay Soil Plantation & Clay Soil Native \\
\hline & \multicolumn{4}{|c|}{ Total C } \\
\hline $0-25 \mathrm{~cm}$ & $41.4 \mathrm{a}$ & $43.8 \mathrm{a}$ & $64.1 \mathrm{a}$ & $81.2 \mathrm{a}$ \\
\hline \multirow[t]{2}{*}{$25-60 \mathrm{~cm}$} & $49.7 \mathrm{a}$ & $43.2 \mathrm{a}$ & $50.4 \mathrm{a}$ & $37.3 \mathrm{a}$ \\
\hline & \multicolumn{4}{|c|}{ Bulk density } \\
\hline $0-25 \mathrm{~cm}$ & $1.21 \mathrm{a}$ & $1.43 \mathrm{a}$ & $1.20 \mathrm{a}$ & $1.17 \mathrm{a}$ \\
\hline $25-60 \mathrm{~cm}$ & $1.28 \mathrm{a}$ & $1.30 \mathrm{a}$ & $1.12 \mathrm{a}$ & $1.12 \mathrm{a}$ \\
\hline
\end{tabular}


in aggregates in the $0-20 \mathrm{~cm}$ layer of the clay soil showed that there were no changes in the amount of SMAG $(p=0.16)$ or MIAG $(p=0.18)$ due to the forest type (Table 4). The SMAG fractions in the $30-50 \mathrm{~cm}$ layer of the clay soil did not vary due to the forest type $(p=0.8$; Table 4$)$, but there were $54 \%$ more MIAG in the $30-50 \mathrm{~cm}$ layer in the plantation soil $(p=0.01)$. The MIAG in the $30-50 \mathrm{~cm}$ layer under cultivation in the clay soil had greater mass, $\mathrm{C}$ content and $\mathrm{C}$ concentration than the MIAG in the $30-50 \mathrm{~cm}$ layer under native forest in the clay soil ( $\mathrm{p}=0.02$, all tests).

The sandy soil, on the other hand, showed no changes in the masses of aggregate fractions due to forest type. The SMAG masses from the $0-20 \mathrm{~cm}$ (87.8 and $88.5 \mathrm{~g}$ in native and plantation forest, respectively), and $30-50 \mathrm{~cm}$ layers (78.8 and $81.5 \mathrm{~g}$ in native and plantation forest, respectively), closely paralleled the soil sand particle percentage (910 and $820 \mathrm{~g} \mathrm{~kg}^{-1}$ in the layers $0-20$ and $30-50 \mathrm{~cm}$, respectively; Table 1). The only significant differences were found for $\mathrm{C}$ concentration in the $30-50 \mathrm{~cm}$ layer. The SMAG in plantation soil had a higher C concentration than the SMAG in the sandy native forest soil $(p=0.02)$, and the MIAG from the native forest soil had a higher $\mathrm{C}$ concentration than the MIAG in plantation soil $(\mathrm{p}=0.03$; Table 4$)$.

Table 4. Small macro-aggregate (SMAG) and microaggregate (MIAG) mass and carbon partitioning in native and plantation forests on clay and sandy soils

\begin{tabular}{lrrrr}
\hline & \multicolumn{4}{c}{ SMAG MIAG } \\
\cline { 2 - 5 } & $\mathbf{0 - 2 0} \mathbf{~ c m ~}$ & $\mathbf{3 0 - 5 0} \mathbf{~ c m}$ \\
\hline & \multicolumn{4}{c}{ Mass $(\mathrm{g})$} \\
Clay soil native & $33.5 \mathrm{a}$ & $12.0 \mathrm{a}$ & $44.2 \mathrm{a}$ & $8.7 \mathrm{~b}$ \\
Clay soil plantation & $43.8 \mathrm{a}$ & $13.3 \mathrm{a}$ & $43.1 \mathrm{a}$ & $13.4 \mathrm{a}$ \\
Sandy soil native & $87.8 \mathrm{a}$ & $5.0 \mathrm{a}$ & $78.8 \mathrm{a}$ & $9.7 \mathrm{a}$ \\
Sandy soil plantation & $88.5 \mathrm{a}$ & $5.0 \mathrm{a}$ & $81.5 \mathrm{a}$ & $9.1 \mathrm{a}$ \\
& & C content $(\mathrm{mg})$ \\
Clay soil n ative & $1147 \mathrm{a}$ & $356 \mathrm{a}$ & $590 \mathrm{a}$ & $109 \mathrm{~b}$ \\
Clay soil plantation & $1030 \mathrm{a}$ & $376 \mathrm{a}$ & $586 \mathrm{a}$ & $202 \mathrm{a}$ \\
Sandy soil native & $245 \mathrm{a}$ & $141 \mathrm{a}$ & $164 \mathrm{a}$ & $190 \mathrm{a}$ \\
Sandy soil plantation & $266 \mathrm{a}$ & $287 \mathrm{a}$ & $240 \mathrm{a}$ & $152 \mathrm{a}$ \\
& $\mathrm{C}$ concentration $\left(\mathrm{g} \mathrm{kg} \mathrm{kg}^{-1}\right)$ \\
Clay soil native & $11.74 \mathrm{a}$ & $3.75 \mathrm{a}$ & $0.83 \mathrm{a}$ & $0.29 \mathrm{~b}$ \\
Clay soil plantation & $10.48 \mathrm{a}$ & $3.90 \mathrm{a}$ & $0.85 \mathrm{a}$ & $1.04 \mathrm{a}$ \\
Sandy soil native & $2.64 \mathrm{a}$ & $1.60 \mathrm{a}$ & $1.83 \mathrm{~b}$ & $2.22 \mathrm{a}$ \\
Sandy soil plantation & $2.85 \mathrm{a}$ & $1.96 \mathrm{a}$ & $2.62 \mathrm{a}$ & $1.74 \mathrm{~b}$
\end{tabular}

Significant differences between forest types within a soil texture at $\alpha \leq 0.05$ are indicated by different letters within a column for each depth. Masses are g resulting from an initial $100 \mathrm{~g}$ oven-dry soil. Sand, silt, and clay derived from clay soil
aggregates

The fractionation of SMAG and MIAG revealed that sand-sized particles increased ( $p=0.01$ for all tests) in SMAG of the plantation soil at both depths, and in MIAG in the 0-20 cm layer (Table 5). These changes in mass were not accompanied by any differences in $\mathrm{C}$ contents and concentrations.

Associated with the increase in the sand size fractions of the clay plantation soil SMAG and MIAG soil aggregates, there was a corresponding decrease in the silt and clay size fractions (Table 5). For example, the clay fraction of the SMAG in the $0-20 \mathrm{~cm}$ layer in the plantation soil was $96 \%$ lower $(p=0.01)$ than in the native forest soil. Similar statistically significant decreases were found in the SMAG silt fraction in the layers $0-20 \mathrm{~cm}(\mathrm{p}=0.02)$, and 30$50 \mathrm{~cm}(\mathrm{p}=0.01)$, and in the clay fraction of the MIAG in the $0-20 \mathrm{~cm}$ layer $(p=0.04)$. These changes in mass were accompanied by significant differences in $\mathrm{C}$ contents and concentrations of silt and clay fractions. The decrease in silt mass was accompanied by a lower $\mathrm{C}$ content and concentration in the SMAG silt in both layers $(p=0.04$, both tests; Table 5$)$. The decrease in clay mass in the plantation soil SMAG in 0-20 cm, and in MIAG in the 0-20 cm layer was also accompanied by a decrease in the $\mathrm{C}$ contents and concentrations ( $\mathrm{p}=0.04$ and 0.01 , respectively).

\section{Sand, silt, and clay derived from sandy soil aggregates}

Sandy native forest soil was found to have statistically significant increases in the mass of silt and clay in the SMAG and MIAG at both depths (Table 6). Sand increased only in the native forest MIAG in the $30-50 \mathrm{~cm}$ layer $(\mathrm{p}=0.04)$.

In the 0-20 cm layer silt and clay increased in sandy plantation soil SMAG, and silt increased in plantation MIAG at the same depth ( $\mathrm{p} £ 0.02$, all tests). At $30-50 \mathrm{~cm}$, plantation SMAG increased in silt content $(p=0.03)$, while plantation MIAG increased in silt and clay contents $(p=0.02$, all tests). All of these changes of silt and clay in the plantation soils were accompanied by increases in $\mathrm{C}$ contents and concentrations, except for the $\mathrm{C}$ concentration in the SMAG 30-50 cm layer, where the difference was nonsignificant (Table 6).

\section{DISCUSSION}

The $\mathrm{C}$ stocks found in this study (Table 3) are within the range of data published in the literature for these soil types in the Amazon region. Silver et al. (2000) found $113 \mathrm{Mg} \mathrm{ha}^{-1}$ of $\mathrm{C}$ in a sandy soil (Ultisol) and $101 \mathrm{Mg} \mathrm{ha}^{-1}$ of $\mathrm{C}$ in a clay soil (Oxisol) at one meter depth in the Tapajós National Forest in Amazônia. Moraes et al. (1995) reported that, from a survey of 1,162 soil pits across the entire Brazilian Amazon, soil C stocks at one meter depth range from 23 to $217 \mathrm{Mg} \mathrm{ha}^{-1}$ of $\mathrm{C}$ for all soil classifications, with a range of 85 to $105 \mathrm{Mg} \mathrm{ha}^{-1}$ of $\mathrm{C}$ for Oxisols. There were no statistical differences for soil C stocks between 
Table 5. Mass and C components of sand, silt, and clay fractions from SMAG and MIAG in native and plantation forests of the clay soil

\begin{tabular}{|c|c|c|c|c|c|c|}
\hline & \multicolumn{3}{|c|}{ SMAG $(250-2000 \mu \mathrm{m})$} & \multicolumn{3}{|c|}{ MIAG $(53-250 \mu \mathrm{m})$} \\
\hline & Sand & Silt & Clay & Sand & Silt & Clay \\
\hline & \multicolumn{6}{|c|}{ Mass (g) } \\
\hline $0-20 \mathrm{~cm}$ Native & $27.7 \mathrm{~b}$ & $3.2 \mathrm{a}$ & $1.8 \mathrm{a}$ & $8.9 \mathrm{~b}$ & $1.8 \mathrm{a}$ & $0.61 \mathrm{a}$ \\
\hline Plantation & $39.5 \mathrm{a}$ & $2.5 \mathrm{~b}$ & $0.1 \mathrm{~b}$ & $10.9 \mathrm{a}$ & $1.6 \mathrm{a}$ & $0.25 \mathrm{~b}$ \\
\hline $30-50 \mathrm{~cm}$ Native & $27.5 \mathrm{~b}$ & $14.7 \mathrm{a}$ & $1.5 \mathrm{a}$ & $4.1 \mathrm{a}$ & $2.6 \mathrm{a}$ & $1.3 \mathrm{a}$ \\
\hline \multirow[t]{2}{*}{ Plantation } & $32.9 \mathrm{a}$ & $7.1 \mathrm{~b}$ & $2.4 \mathrm{a}$ & $7.6 \mathrm{a}$ & $3.4 \mathrm{a}$ & $2.0 \mathrm{a}$ \\
\hline & \multicolumn{6}{|c|}{$\mathrm{C}$ content (mg) } \\
\hline 0-20 cm Native & $1013 \mathrm{a}$ & 97 a & $36 \mathrm{a}$ & $287 \mathrm{a}$ & $59 \mathrm{a}$ & $10 \mathrm{a}$ \\
\hline Plantation & 946 a & $69 \mathrm{~b}$ & $14 \mathrm{~b}$ & $330 \mathrm{a}$ & $42 \mathrm{a}$ & $4.1 \mathrm{~b}$ \\
\hline $30-50 \mathrm{~cm}$ Native & $413 \mathrm{a}$ & $161 \mathrm{a}$ & $16 \mathrm{a}$ & $63 \mathrm{a}$ & $35.3 \mathrm{a}$ & $10.7 \mathrm{a}$ \\
\hline \multirow[t]{2}{*}{ Plantation } & $467 \mathrm{a}$ & $95 \mathrm{~b}$ & $24 \mathrm{a}$ & $119 \mathrm{a}$ & $46.5 \mathrm{a}$ & $36.0 \mathrm{a}$ \\
\hline & \multicolumn{6}{|c|}{$\mathrm{C}$ concentration (mg.kg-11) } \\
\hline 0-20 cm Native & $1570 \mathrm{a}$ & $160 \mathrm{a}$ & $50 \mathrm{a}$ & $430 \mathrm{a}$ & $90 \mathrm{a}$ & $20 \mathrm{a}$ \\
\hline Plantation & $1380 \mathrm{a}$ & $100 \mathrm{~b}$ & $2 \mathrm{~b}$ & $500 \mathrm{a}$ & $60 \mathrm{a}$ & $6 \mathrm{~b}$ \\
\hline $30-50 \mathrm{~cm}$ Native & $50 \mathrm{a}$ & $30 \mathrm{a}$ & $2 \mathrm{a}$ & $8 \mathrm{a}$ & $5 \mathrm{a}$ & $1 \mathrm{a}$ \\
\hline Plantation & $60 \mathrm{a}$ & $10 \mathrm{~b}$ & $5 \mathrm{a}$ & $10 \mathrm{a}$ & $10 \mathrm{a}$ & $4 \mathrm{a}$ \\
\hline
\end{tabular}

Significant differences between forest types within a soil texture at $\alpha \leq 0.05$ are indicated by different letters within a column for each depth. Masses are g resulting from masses of SMAG or MIAG in Table 4.

Table 6. Mass and $\mathrm{C}$ components of sand, silt, and clay fractions from small macro-aggregates (SMAG) and micro-aggregates (MIAG) of the sandy soil

\begin{tabular}{|c|c|c|c|c|c|c|c|}
\hline & & \multicolumn{3}{|c|}{ SMAG $(250-2000 \mu \mathrm{m})$} & \multicolumn{3}{|c|}{ MIAG $(53-250 \mu \mathrm{m})$} \\
\hline & & Sand & Silt & Clay & Sand & Silt & Clay \\
\hline & & \multicolumn{6}{|c|}{ Mass (g) } \\
\hline \multirow[t]{2}{*}{$0-20 \mathrm{~cm}$} & Native & $86.9 \mathrm{a}$ & $0.15 \mathrm{~b}$ & $0.14 \mathrm{~b}$ & $4.55 \mathrm{a}$ & $0.07 \mathrm{~b}$ & $0.05 \mathrm{a}$ \\
\hline & Plantation & $86.7 \mathrm{a}$ & $0.49 \mathrm{a}$ & $0.34 \mathrm{a}$ & $4.45 \mathrm{a}$ & $0.21 \mathrm{a}$ & $0.07 \mathrm{a}$ \\
\hline \multirow{3}{*}{\multicolumn{2}{|c|}{$\begin{array}{l}30-50 \mathrm{~cm} \text { Native } \\
\text { Planta tion }\end{array}$}} & $78.0 \mathrm{a}$ & $0.2 \mathrm{~b}$ & $0.24 \mathrm{a}$ & $8.73 \mathrm{a}$ & $0.32 \mathrm{~b}$ & $0.16 \mathrm{~b}$ \\
\hline & & $80.4 \mathrm{a}$ & $0.43 \mathrm{a}$ & $0.42 \mathrm{a}$ & $7.8 \mathrm{~b}$ & $0.47 \mathrm{a}$ & $0.30 \mathrm{a}$ \\
\hline & & \multicolumn{6}{|c|}{$\mathrm{C}$ content (mg) } \\
\hline \multirow[t]{2}{*}{$0-20 \mathrm{~cm}$} & Native & $218 \mathrm{a}$ & $16 \mathrm{~b}$ & $11.6 \mathrm{~b}$ & $128 \mathrm{a}$ & $8.8 \mathrm{~b}$ & $4.8 \mathrm{~b}$ \\
\hline & Plantation & $171 \mathrm{a}$ & $68 \mathrm{a}$ & $27 \mathrm{a}$ & $242 \mathrm{a}$ & $36 \mathrm{a}$ & $8.8 \mathrm{a}$ \\
\hline \multirow{3}{*}{\multicolumn{2}{|c|}{$\begin{array}{l}\text { 30-50 cm Native } \\
\text { Plantation }\end{array}$}} & $142 \mathrm{a}$ & $11.4 \mathrm{~b}$ & $10.5 \mathrm{a}$ & $164 \mathrm{a}$ & $18 \mathrm{~b}$ & $8.4 \mathrm{~b}$ \\
\hline & & $200 \mathrm{a}$ & $22.3 \mathrm{a}$ & $17.5 \mathrm{a}$ & $105 \mathrm{a}$ & $31.0 \mathrm{a}$ & $15.3 \mathrm{a}$ \\
\hline & & \multicolumn{6}{|c|}{$\mathrm{C}$ concentration $\left(\mathrm{mg} \mathrm{kg}^{-1}\right)$} \\
\hline \multirow[t]{2}{*}{$0-20 \mathrm{~cm}$} & Native & $17.4 \mathrm{a}$ & $0.16 \mathrm{~b}$ & $1.0 \mathrm{~b}$ & $13.6 \mathrm{~b}$ & $0.9 \mathrm{~b}$ & $0.5 \mathrm{~b}$ \\
\hline & Plantation & $17.3 \mathrm{a}$ & $6.8 \mathrm{a}$ & $3.0 \mathrm{a}$ & $26.7 \mathrm{a}$ & $3.8 \mathrm{a}$ & $1.0 \mathrm{a}$ \\
\hline \multicolumn{2}{|c|}{$30-50 \mathrm{~cm}$ Native } & $15.6 \mathrm{a}$ & $1.2 \mathrm{a}$ & $1.2 \mathrm{a}$ & $17.4 \mathrm{a}$ & $1.9 \mathrm{~b}$ & $1.0 \mathrm{a}$ \\
\hline & Plantation & $24.1 \mathrm{a}$ & $2.2 \mathrm{a}$ & $1.7 \mathrm{a}$ & $7.8 \mathrm{a}$ & $3.3 \mathrm{a}$ & $1.5 \mathrm{a}$ \\
\hline
\end{tabular}

Significant differences between forest types within a soil texture at $\alpha \leq 0.05$ are indicated by different letters within a column for each depth. Masses are g resulting from masses of SMAG or MIAG in Table 4.

forest types within a soil texture. Lima et al. (2006) found that Eucalyptus plantations increased soil C stocks on a Typic Haplustox in Brazil planted on land formerly used as pasture. Zinn et al. (2002) found a decrease of $23 \%$ in SOM in the $0-5 \mathrm{~cm}$ layer of a loamy Oxisol under Eucalyptus in the Brazilian cerrado, but observed no changes below this depth. In terms of the absolute value of the soil $\mathrm{C}$ stocks $\left(\mathrm{Mg} \mathrm{ha}^{-1}\right.$ of $\left.\mathrm{C}\right)$, the differences in the sandy forest soil were smaller at all depths than in the clay forest soil. 
For example, the $\mathrm{C}$ stock ( $\mathrm{Mg}$ ha ${ }^{-1}$ of $\mathrm{C}$ ) in the $0-25 \mathrm{~cm}$ layer in the sandy plantation soil was 41.4 and 43.8 in the sandy native forest soil, whereas the clay plantation soil had 64.1 and the clay native forest soil had 81.2. The difference between the two clay forest soils is much larger than that of the sandy forest soils.

The aggregate analysis showed that the mass, $\mathrm{C}$ contents and $\mathrm{C}$ concentrations of SMAG and MIAG of native and plantation soils were not very different (Table 4). The increase in mass and $\mathrm{C}$ content and concentration of MIAG $30-50 \mathrm{~cm}$ in the clay plantation soil suggested that the current silvicultural management stimulated the natural aggregation processes in the clay soil. The increase in plantation soil MIAG could be related to surface organic matter incorporation through soil tillage (Christensen, 1986). These mechanisms would promote increased aggregation of individual clay and silt particles into micro-aggregates (Hassink et al., 1997; Chan \& Heenan, 1999). This is a potentially positive result for soil structure and sustainability as soil aggregate formation facilitates the protection and accrual of $\mathrm{C}$ (Jastrow, 1996; Christensen, 2001; Skjemstad et al., 2008). The sandy soil showed no change in aggregation, indicating that management did not influence the aggregate formation process. The low clay content of this soil ( 7 and $15 \%$ in the layers $0-25$ and $25-60 \mathrm{~cm}$, respectively; Table 1) confers a low aggregation potential (Christensen, 1986).

The particle size fractionation at both depths in the clay soil (Table 5) showed a trend of increased sand mass and a decrease in silt and clay in aggregates, accompanied by a decrease in $\mathrm{C}$ contents and concentrations in the plantation soils (Table 5). The increase in sand particles in aggregates in the clay plantation soil is probably due to soil tillage during site preparation which mixed sand, silt and clay particles, and organic matter that eventually form sand-sized aggregates (Christensen, 1996). The increase in sand content in aggregates in the clay plantation soil was not accompanied by any statistically significant changes in $\mathrm{C}$ contents or concentrations, but the decrease in silt and $\mathrm{C}$ content and concentration in both aggregate types and depths indicates that management reduced within-aggregate carbon. The small decreases in within-aggregate silt and clay and their $\mathrm{C}$ contents in the clay plantation soil, although potentially important in terms of soil structure, do not indicate that $\mathrm{C}$ has shifted to greater physical protection within the soil aggregate structure.

The particle size fractionation by SMAG and MIAG of the sandy plantation soils revealed an opposite trend in differences to native forest, with increasing silt and clay mass within aggregates. There was a general trend of increase in silt and clay particle mass and C content in aggregates of the sandy plantation soils for each aggregate type at each depth (Table 6), which is a clear indication of a shift in mass from larger to smaller soil fractions. For example, the silt mass of
SMAG $0-20 \mathrm{~cm}$ was 3.2 times greater in the plantation, and the $\mathrm{C}$ content and concentration were 4.3 and 42 times greater, respectively (Table 6). The clay fraction in SMAG 0-20 cm increased in mass by a factor of 2.4, and in $\mathrm{C}$ content and concentration by a factor of 2.3 and 3, respectively, compared to the clay fraction in SMAG of the native forest soil. The trend was the same for MIAG, with increasing silt, clay, and $\mathrm{C}$ contents and concentrations in the plantation soils at both depths, and these changes in the MIAG fractions indicate a possible shift of $\mathrm{C}$ to the smaller, less labile soil fractions. In combination with the decrease in the sand fraction and the increase in silt and clay fraction masses, these changes in mass, content, and concentration support the hypotheses that $\mathrm{C}$ would shift to greater physical protection in the soil aggregate structure. Alterations or increases in $\mathrm{C}$ in the silt- and clay-sized fractions in soils under cultivation have been reported in the literature for the Brazilian Amazon (Shang \& Tiessen, 1997; Zinn et al., 2002) and elsewhere (Tiessen \& Stewart, 1983). These shifts, albeit very small in magnitude, indicate that the organic matter in the sandy plantation soils is changing to more stabile forms within the soil aggregate structure and could therefore be less available for short-term cycling.

\section{CONCLUSIONS}

1. Silvicultural management did not reduce total $\mathrm{C}$ stocks or influence soil bulk density.

2. The effect of soil texture on total $\mathrm{C}$ was demonstrated in the upper profile of the clay soil where total $\mathrm{C}$ was higher than in the sandy soil.

3. Silvicultural activities have induced changes in SOM aggregate and particle-size fraction dynamics, in comparison with conditions of native forests on both soil types. The aggregate mass of the managed soils did not decrease, indicating that the decreases in soil aggregation in either soil texture caused by soil cultivation in six-year cycles are not large.

4. Silt, clay, and C shifted to greater aggregate protection in the sandy plantation soil, representing a decrease in $\mathrm{C}$ availability. The clay plantation soil, on the other hand, lost $\mathrm{C}$ in the silt and clay fractions, whereas the labile organic matter contained within aggregates increased, due to an increase in sand-sized mineral/organic fractions, while this shift from $\mathrm{C}$ to structural forms considered more protected was not observed.

\section{ACKNOWLEDGEMENTS}

The authors would like to thank Jari Celulose, S.A., for granting access to the research sites and for cooperation in all phases of this research, and Robin 
Governo for helping with the laboratory analyses. This study was kindly supported by a grant of the NASA Large-scale Biosphere-Atmosphere experiment in Amazonia.

\section{LITERATURE CITED}

ARACRUZ. O Eucalipto Aracruz. Access under: http:// w w w . a r a r u z.com.br/show_press.do? act $=$ stcNews\&id $=35 \&$ lastRoot $=10 \&$ lang $=1>$. Access date: Feb. 11, 2009.

BAUCH, R.E.; KIKUCHI, M.Y. \& PIRES, J.S.R. Forest plantation management certification evaluation of Jari Celulose S.A. in the State of Pará and Amapá, Brazil. Report of Science Certification Systems Forest Conservation Program. 2005. Access under: < http:// www.scscertified.com/PDFS/forest_jari_eng.pdf $>$. Access date: Nov., 12, 2008.

BLAKE, T.T. \& HARTAGE, K.H. Bulk density. In: KLUTE, A., ed. Methods of soil analysis. Part I. Physical and mineralogical methods. Madison, SSSA/ASA, 1986. p.364366 .

CAMBARDELLA, C.A. \& ELLIOT, E.T. C and N dynamics of soil organic matter fractions from cultivated grassland soils. Soil Sci. Soc. Am. J., 58:123-130, 1994.

CHAN, K.Y. \& HEENAN, D.P. Microbial-induced soil aggregate stability under different crop rotations. Biol. Fert. Soils, 30:29-32, 1999 .

CHRISTENSEN, B.T. Straw incorporation and soil organic matter in macro-aggregates and particle-size separates. J. Soil Sci., 37:125-135, 1986

CHRISTENSEN, B.T. Carbon in primary and secondary organo-mineral complexes. In: CARTER, M.R. \& STEWART, B.A., eds. Structure and organic matter storage in agricultural soils. Boca Raton, CRC Press, 1996. p.97-165.

CHRISTENSEN, B.T. Physical fractionation of soil and structural and functional complexity in organic matter turnover. Eur. J. Soil Sci., 52:345-353, 2001.

EDWARDS, A.P. \& BREMNER, J.M. Microaggregates in soils. J. Soil Sci., 18:64-73, 1967.

ELLIOT, E.T. \& CAMBARDELLA, C.A. Physical separation of soil organic matter. Agric. Ecosyst. Environ., 34:407-419, 1991.

FEARNSIDE, P.M. Jari at age 19: lessons for Brazil's silvicultural plans at Carajás. R. Interci., 13:12-24, 1988.

FISHER, R.F. \& BINKLEY, D. Ecology and management of forest soils. 3.ed. New York, John Wiley \& Sons, 2000. 489 .

GREGORICH, E.G.; VORONEY, R.P. \& KACHANOSKI, R.G. Turnover of carbon through microbial biomass in soils of different textures. Soil Biol. Biochem., 23:799-805, 1991.
HASSINK, J.; WHITMORE, A.P. \& KUBÁT, J. Size and density fractionation of soil organic matter and the physical capacity of soils to protect organic matter. Eur. J. Agron., 7:189-199, 1997.

JACKSON, M.L. Soil chemical analysis: Advanced course. Madison, University of Wisconsin, , 1956.

JARI. Atividade operacional florestal. Access under: < http:// www.jari.com.br/web/pt/operacoes/florestal.htm>. Access date: Nov. 10, 2008.

JASTROW, J.D. Soil aggregate formation and the accrual of particulate and mineral-associated organic matter. Soil Bio. Biochem., 28:665-676, 1996.

LIMA, A.M.N.; SILVA, I.R.; NEVES, J.C.L.; NOVAIS, R.F.; BARROS, N.F.; MENDONÇA, E.S.; SMYTH, T.J.; MOREIRA, M.S. \& LEITE, F.P. Soil organic carbon dynamics following afforestation of degraded pastures with eucalyptus in Southeastern Brazil. For. Ecol. Manag., 235:219-231, 2006.

LÜTZOW, M.V.; KÖGEL-KNABNER, I.; EKSCHMITT, K.; FLESSA, H.; GUGGENBERGER, G.; MATZNER, E. \& MARSCHNER, B. SOM fractionation methods: Relevance to functional pools and to stabilization mechanisms. Soil Biol. Biochem., 39:2183-2207, 2007.

MAQUERE, V.; LACLAU, J.P.; BERNOUX, M.; SAINTANDRE，L.; GONCALVES，J.L.M.; CERRI，C.C.; PICCOLO, M.C. \& RANGER, J. Influence of land use (savanna, pasture, Eucalyptus plantations) on soil carbon and nitrogen stocks in Brazil. Eur. J. Soil Sci., 59:863877, 2008.

MCNABB, K.L.; BORGES, J. \& WELKER, J. Jari at 25. J. For., 2:21-26, 1994

MCNABB, K.L. \& WADAUSKI, L. Multiple rotation yields for intensively managed plantations in the Amazon basin. New For., 18:5-15, 1999.

MORAES, J.L.; CERRI, C.C.; MELILLO, J.M.; KICKLIGHTER, D.; NEILL, C.; SKOLE, D.L. \& STEUDLER, P.A. Soil carbon stocks of the Brazilian Amazon basin. Soil Sci. Soc. Am. J., 59:244-247, 1995.

SAS Institute. Version 8.1. SAS Campus Drive. Cary, 2001.

SOCIEDADE BRASILEIRA DE SILVICULTURA - SBS. Área plantada com Pinus e Eucaliptos no Brasil. Access under: $<$ http://www.sbs.org.br/estatisticas.htm>. Access date: Jan. 25, 2009 .

SHANG, C. \& TIESSEN, H. Organic matter lability in a tropical Oxisol: Evidence from shifting cultivation, chemical oxidation, particle size, density, and magnetic fractionations. Soil Sci., 162:795-807, 1997.

SHANG, C. \& TIESSEN, H. Organic matter stabilization in two semi-arid tropical soils: Size, density, and magnetic separations. Soil Sci. Soc. Am. J., 62:1247-1257, 1998.

SILVER, W.L.; NEFF, J.; MCGRODDY, M.; VELDKAMP, E.; KELLER, M. \& COSME, R. Effects of soil texture on belowground carbon and nutrient storage in a lowland Amazonian forest ecosystem. Ecosystems, 3:193-209, 2001. 
SINPAPEL. Retrospectiva: Mesmo com crise, setor comemora. Access under: <http://www.sinpapel.com.br/Noticias/ noticias1642.html>. Access date: Dec. 29, 2008.

SIX, J.; MERCKX, R.; KIMPE, K.; PAUSTIAN, K. \& ELLIOT, E.T. A re-evaluation of the enriched labile soil organic matter fraction. Eur. J. Soil Sci., 51:283-293, 2000.

SKJEMSTAD, J.O.; KRULL, E.S.; SWIFT, R.S. \& SZARVAS, S. Mechanisms of protection of soil organic matter under pasture following clearing of rainforest on an Oxisol. Geoderma, 143: 231-242, 2008.

SOLLINS, P.; HOMANN, P. \& CALDWELL, B.A. Stabilization and destabilization of soil organic matter: Mechanisms and controls. Geoderma, 74:65-105, 1996.

STEEL, R.R. \& TORRIE, J.H. Principles and procedures of statistics: A biometrical approach. 2.ed. New York, McGraw-Hill, 1980. 631p.
TIESSEN, H. \& STEWART, J.W.B. Particle-size fractions and their use in studies of soil organic matter. II. Cultivation effects on organic matter composition in size fractions. Soil Sci. Soc. Am. J., 47:509-514, 1983.

TISDALL, J.M. \& OADES, J.M. Organic matter and waterstable aggregates in soils. J. Soil Sci., 33:141-163, 1982.

UNESCO. The Unesco international classification system and mapping of vegetation, 1973. Access under: http:// unesdoc.unesco.org/images/0000/000050/005032MB.pdf. Access date: Dec. 10, 2008.

ZINN, Y.L.; RESCK, D.V.S. \& SILVA, J.E. Soil organic carbon as affected by afforestation with Eucalyptus and Pinus in the Cerrado region of Brazil. Forest.Ecol. Manag., 166:285-294, 2002.

ZINN, Y.L.; LAL, R. \& RESCK, D.V.S. Changes in soil organic carbon stocks under agriculture in Brazil. Soil Till. Res., $84: 28-40,2005$. 